\title{
AUTISMO: UM TRANSTORNO DE NATUREZA SENSORIAL?
}

\author{
Roberta Costa Caminha
}

O diagnóstico do autismo é feito com base em uma tríade de prejuízos que não faça referência, em momento algum, a problemas sensoriais, embora sejam muitas as evidências de que o transtorno autista seja uma condição diretamente relacionada a um aparato sensorial imperfeito. Considerando-se a importância do aparato sensorial para o desenvolvimento das relaçôes interpessoais do bebê e o fato de $69 \%$ a $80 \%$ dos autistas apresentarem problemas sensoriais, o objetivo do trabalho é iniciar uma reflexão sobre a possível relação da tríade de prejuízos do autismo com um aparato sensorial imperfeito no bebê, começando a se pensar no autismo como, talvez, um transtorno de natureza sensorial.

\section{BANCA:}

Carolina Lampreia (Orientador)

Denise Streit Morsch

Silvia Maria Abu-Jamra Zornig

Data da defesa: $24 / 10 / 2008$ 